https://helda.helsinki.fi

\title{
Carboxylesterase Activities and Protein Expression in Rabbit and Pig Ocular Tissues
}

\section{Hammid, Anam}

2021-03-01

Hammid , A , Fallon , J K , Lassila , T , Salluce , G , Smith , P C , Tolonen , A , Sauer , A , Urtti , A \& Honkakoski , P 2021, ' Carboxylesterase Activities and Protein Expression in

Rabbit and Pig Ocular Tissues ' , Molecular Pharmaceutics, vol. 18 , no. 3 , pp. 1305-1316 . https://doi.org/10.1021/

http://hdl.handle.net/10138/329089

https://doi.org/10.1021/acs.molpharmaceut.0c01154

cc_by

publishedVersion

Downloaded from Helda, University of Helsinki institutional repository.

This is an electronic reprint of the original article.

This reprint may differ from the original in pagination and typographic detail.

Please cite the original version. 


\section{Carboxylesterase Activities and Protein Expression in Rabbit and Pig Ocular Tissues}

Anam Hammid, John K. Fallon, Toni Lassila, Giulia Salluce, Philip C. Smith, Ari Tolonen, Achim Sauer, Arto Urtti, and Paavo Honkakoski*

Cite This: Mol. Pharmaceutics 2021, 18, 1305-1316

Read Online

ACCESS | Lill Metrics \& More | 回 Article Recommendations ｜９） Supporting Information

\begin{tabular}{|l|}
\hline Major ocular tissues \\
- Cornea \\
- Conjunctiva \\
- Aqueous humor \\
- Vitreous \\
- Retina \\
- RPE \\
Preclinical species \\
- Rabbit \\
\hline
\end{tabular}

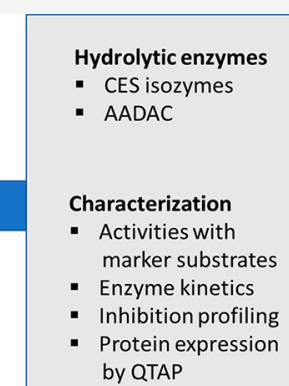

ABSTRACT: Hydrolytic reactions constitute an important pathway of drug metabolism and a significant route of prodrug activation. Many ophthalmic drugs and prodrugs contain ester groups that greatly enhance their permeation across several hydrophobic barriers in the eye before the drugs are either metabolized or released, respectively, via hydrolysis. Thus, the development of ophthalmic drug therapy requires the thorough profiling of substrate specificities, activities, and expression levels of ocular esterases. However, such information is scant in the literature, especially for preclinical species often used in ophthalmology such as rabbits and pigs. Therefore, our aim was to generate systematic information on the activity and expression of carboxylesterases (CESs) and arylacetamide deacetylase (AADAC) in seven ocular tissue homogenates from these two species. The hydrolytic activities were measured using a generic esterase substrate (4-nitrophenyl acetate) and, in the absence of validated substrates for rabbit and pig enzymes, with selective substrates established for human CES1, CES2, and AADAC (D-luciferin methyl ester, fluorescein diacetate, procaine, and phenacetin). Kinetics and inhibition studies were conducted using these substrates and, again due to a lack of validated rabbit and pig CES inhibitors, with known inhibitors for the human enzymes. Protein expression levels were measured using quantitative targeted proteomics. Rabbit ocular tissues showed significant variability in the expression of CES1 (higher in cornea, lower in conjunctiva) and CES2 (higher in conjunctiva, lower in cornea) and a poor correlation of CES expression with hydrolytic activities. In contrast, pig tissues appear to express only CES1, and CES3 and AADAC seem to be either low or absent, respectively, in both species. The current study revealed remarkable species and tissue differences in ocular hydrolytic enzymes that can be taken into account in the design of esterase-dependent prodrugs and drug conjugates, the evaluation of ocular effects of systemic drugs, and in translational and toxicity studies.

KEYWORDS: Ocular tissues, carboxylesterase, arylacetamide deacetylase, pig, rabbit, targeted proteomics

\section{INTRODUCTION}

Hydrolysis plays a vital role in the metabolism or activation of many clinical (pro)drugs, such as cancer therapeutics, opioids, and angiotensin-converting enzyme inhibitors, as well as in lipid hydrolysis and the elimination of potentially toxic xenobiotics. $^{1-3}$ Among many hydrolytic enzymes, carboxylesterases (CES, E.C. 3.1.1.1) are a group of serine hydrolases that cleave esters, amides, thioesters, and carbamates in numerous tissues including liver, kidney, intestine, placenta, heart, brain, and eye. $^{4-8}$ So far, six human, about 20 rodent [including eight Ces $1($ Ces $1 \mathrm{a}-\mathrm{h})$, eight Ces $2(\operatorname{Ces} 2 \mathrm{a}-\mathrm{h})$, two Ces3 (Ces3a-b), and one each of Ces 4 and Ces5 isoforms], ${ }^{9,10}$ three pig, and four rabbit CES proteins have been annotated in the Uniprot database (https://www.uniprot.org/uniprot/?query= CES\&sort=score). Among the five functional human CES enzymes, CES1, and CES2 isoforms are the best-studied and major drug-metabolizing enzymes. ${ }^{11-13}$ In addition, CES1 is a major lipid-hydrolyzing enzyme. ${ }^{3}$ CES1 and CES2 share moderate sequence homology (47\%) and display unique

Received: November 24, 2020

Revised: February 8, 2021

Accepted: February 8, 2021

Published: February 17, 2021 
Table 1. Examples of Drugs Metabolized by CES and AADAC Enzymes

\begin{tabular}{|c|c|c|c|}
\hline enzyme & drug substrates & selective probe substrate & references \\
\hline CES1 & imidapril, enalapril, meperidine, oseltamivir, clopidogrel, heroin, lidocaine, irinotecan, cocaine & D-luciferin methyl ester (DME) & $12-16$ \\
\hline CES2 & prasugrel, irinotecan, capecitabine & fluorescein diacetate (FDA), procaine & 14,16 , and 17 \\
\hline AADAC & rifabutin, rifampicin, indiplon, rifapentine, flutamide & phenacetin & 16 and $18-21$ \\
\hline
\end{tabular}

substrate specificities (Table 1).,11 In a nutshell, substrates with a large acyl group and a small alcohol group are preferably metabolized by CES1. In contrast, CES2 prefers substrates with a small acyl and a large alcohol moiety.

CES1 and CES2 are widely expressed in various tissues of multiple species. CES1 is the major hepatic CES isoform but is also present in the lungs, heart, and adipose tissue, while CES2 is quite abundant in the intestine but also expressed in the kidney, liver, adrenal, and stomach. ${ }^{9}$ The poorly studied CES3 isoform is expressed in the colon, brain, and at lower levels in the liver. It has much lower activity than CES1 or CES2 but may participate in irinotecan hydrolysis and in lipolysis in adipocytes. ${ }^{16,19,22-24}$ The metabolic roles of CES4 and CES5 are unknown, but they are expressed in neuronal cells. ${ }^{25-27}$ CES6 is present in human and mouse cerebellums and is speculated to take part in detoxification within the neural system. $^{28}$ Arylacetamide deacetylase (AADAC) ${ }^{16}$ is another serine hydrolase and has recently emerged as an important drug-metabolizing enzyme with a substrate specificity overlapping with CESs. It is known to prefer substrates with the smallest acyl moieties (Table 1). ${ }^{29}$ The expression of human, rat, mouse, cynomolgus monkey, and $\operatorname{dog}$ AADAC has been found in the liver, kidney, and intestine. ${ }^{27,29}$

The eye is a complex organ composed of multiple cell types in the anterior (conjunctiva, cornea, iris ciliary body, aqueous humor, and lens) and posterior segments (vitreous humor, retina, retinal pigment epithelium (RPE), choroid, and sclera). ${ }^{30}$ However, their capacity for drug metabolism is not very well understood. ${ }^{31}$ The ocular hydrolysis of ester prodrugs has been reported in various species. Examples include the conversion of dipivefrin to epinephrine ${ }^{32,33}$ and the hydrolysis of latanoprost ${ }^{34}$ in rabbit corneal homogenates, and increases in the ocular bioavailability of pilocarpine, ${ }^{35}$ timolol, $^{36}$ and ganciclovir by utilizing their ester prodrugs ${ }^{37,38}$ in corneal and choroidal tissues. Likewise, the cleavage of the carboxylic ester moiety of loteprednol etabonate in rabbit cornea, aqueous humor, and iris-ciliary body highlights the presence and activity of esterases in these tissues. ${ }^{39}$ The hydrolysis of nonspecific esterase substrates such as 4-nitrophenyl acetate (NPA) and naphthyl acetate has been observed in multiple rabbit and bovine ocular tissue homogenates. $8,22,32,37,40,41$ However, the enzymes responsible for these activities have not been characterized beyond the determination of kinetic parameters in a few cases. ${ }^{32}$ A review on global proteomics studies $^{42}$ indicated that CES1 is detectable in most human ocular tissues except aqueous humor but quantitative expression data is nonexistent, and information on CES expression in other species is lacking, hampering translational studies. Finally, there is no knowledge on the ocular expression and activity of AADAC in the literature. ${ }^{43}$ To understand the biotransformation capacity in the eye and the risk of the formation of toxic metabolites from extended drug exposure from ocular implants, the metabolic profiling of individual ocular tissues in all preclinical species and in humans is crucial. A more detailed characterization of the catalytic and expression properties of ocular esterases is also important in the design of ophthalmic (pro)drugs and drug conjugates and in understanding the hydrolysis of drugs entering the eye from the systemic circulation.

Therefore, we aimed to characterize the activities and protein expression of CES1, CES2, and CES3 isoforms and AADAC that are metabolically active among mammalian species. Because of the unavailability of recombinant CES enzymes and the lack of information on their substrate selectivity in rabbits and pigs, multiple substrates characterized for the corresponding human CES enzymes were used. Kinetic and inhibition studies in select tissues with the highest activities were conducted. Finally, we performed a quantitative targeted proteomic analysis of the tissues to provide a systematic analysis of ocular hydrolytic enzymes in these two common preclinical species.

\section{MATERIALS AND METHODS}

Chemicals and Reagents for Enzymatic Assays. 4Nitrophenyl acetate (NPA), 4-nitrophenol, acetonitrile (ACN), fluorescein diacetate (FDA), D-luciferin, Bio-Rad protein assay dye reagent (\# 500-0006), diltiazem hydrochloride (purity $\geq 99 \%$ ), timolol maleate salt ( $\geq 98 \%$ ), verapamil hydrochloride ( $\geq 99 \%$ ), fluorescein, bovine serum albumin (BSA), phenylmethylsulfonyl fluoride (PMSF), protease inhibitor cocktail (\#P8340), phenacetin, $p$-phenetidine $(\geq 99.9 \%)$, acetaminophen, procainamide- $\mathrm{HCl}(\geq 98 \%)$, procaine- $\mathrm{HCl}(>97 \%)$, $p$ aminobenzoic acid (PABA), potassium phosphate buffer (PBS), and dimethyl sulfoxide (DMSO; $\geq 99.9 \%$ ) were purchased from Sigma-Aldrich Finland Oy (Espoo, Finland). Dulbecco's phosphate-buffered saline $(10 \times$ DPBS; \# 14200166) and phosphate-buffered saline (PBS) were obtained from Thermo Fisher. Luciferin methyl ester (DME) was purchased from the AAT bioquest (Sunnyvale, CA). QuantiLum recombinant luciferase (rLuciferase) was from Promega (Madison, WI). Digitonin $(\geq 99 \%)$ was purchased from Merck Life Science (Merck KGaA, Darmstadt, Germany). All other chemicals were at least analytical grade.

Chemicals and Reagents for Targeted Proteomics. Synthetic stable isotope-labeled (SIL) peptides (SpikeTides_TQL) that are isotopically labeled and quantified (Table 2) were obtained from JPT Peptide Technologies $\mathrm{GmbH}$ (Berlin, Germany). Guanidine hydrochloride, sodium hydroxide, dithiothreitol (DTT), ammonium hydrocarbonate, iodoacetamide, chloroform, methanol, MS-grade $\mathrm{ACN}$, formic acid, sodium-EDTA, Trizma (Tris base), and all other chemicals and reagents were from Sigma (Saint Louis, MO). ProteaseMAX, sequencing-grade lysyl endopeptidase LysC, TPCK-treated trypsin, and urea were from Promega (Madison, WI). Solid phase extraction (SPE) cartridges were Strata-X, $33 \mu \mathrm{m}$, polymeric reversed phase (Part \# 8B-S100-AAK) (10 mg/ $\mathrm{mL}$ ) purchased from Phenomenex (Torrance, $\mathrm{CA}$ ).

Extraction and Homogenization of Ocular Tissues. Pig eyes were obtained from a local slaughterhouse (Lankamainen, Kuopio, Finland). The pig eyes were removed, cooled immediately on ice, and kept on ice during transportation to the laboratory. The delay from eye removal to receipt at the 
Table 2. List of Peptides Used for CESs and AADAC in Multiple Species ${ }^{a}$

\begin{tabular}{|c|c|c|}
\hline enzyme & peptides sequences & species (UniProt ID) \\
\hline \multirow[t]{2}{*}{ CES1 } & SYPIVNVSK $* 392$ & rabbit $(\mathrm{P} 12337)$ \\
\hline & FWANFAR $* 505,503,468$ & human (P23141), rat (Q63108), pig (F1RF16) \\
\hline \multirow[t]{3}{*}{ CES2 } & NIAHFGGNPGR $* 194$ & rabbit (G1T7P3) \\
\hline & ADHGDELPFVFR $* 466$ & human (O00748) \\
\hline & AGVHTFLGIPFAK $* 67$ & rat (A0A0G2K455) \\
\hline \multirow[t]{7}{*}{ CES3 } & LAFPEATEEEK ${ }^{490}$ & human (Q6UWW8), rabbit (G1SNB1) \\
\hline & ATGPETAQPEVDTALGR*42 & rabbit (G1SNB1) \\
\hline & TIASYTVDGTFFPK ${ }^{322}$ & pig (I3LEI5) \\
\hline & EATQPEVDTTLGR $* 42$ & \\
\hline & NTIYPLTVDGTVFPK $* 323$ & human (Q6UWW8) \\
\hline & TPEEILAEK $* 338$ & rat $(\mathrm{P} 16303)$ \\
\hline & FAPPQPAEPWNFVK $* 78$ & \\
\hline \multirow[t]{4}{*}{ AADAC } & FWSEYFTTDR ${ }^{258,258,257}$ & human (P22760), pig (A0A287AXR4), rat (Q9QZH8) \\
\hline & YPGFLDVR $* 318,318,317$ & human (P22760), pig (A0A287AXR4), rabbit (Q7M370) \\
\hline & TPTPGSLELAQK $* 309$ & rat (Q9QZH8) \\
\hline & LDVVVVSTNYR $^{145}$ & rabbit (Q7M370) \\
\hline $\mathrm{Na}^{+} / \mathrm{K}^{+}$ATPase & AAVPDAVGK* & all species \\
\hline
\end{tabular}

${ }^{a}$ The bold $\mathbf{K} / \mathbf{R}$ indicate the ${ }^{13} \mathrm{C}$ - and ${ }^{15} \mathrm{~N}$-labeled residues required for quantitation. The number is the $\mathrm{C}$-terminal residue of the peptide in the respective protein, or when the peptide is common for multiple species, the number is for the human isoform. SpikeTides_TQL peptides were used as internal standards. The C-terminal tetrapeptide tag on these is cleaved by the protease digestion. A peptide cocktail $(20 \mathrm{nM}$ each $)$ used for simultaneous MRM quantitation was prepared in $0.1 \mathrm{M}$ ammonium bicarbonate solution and ACN (1:4). Peptides marked with an asterisk (*) were used for protein quantitation. Note: the pig CES2 gene is absent from the reference genome [UCSC Genome Browser assembly ID: susScr11].

laboratory was maximally $2-3 \mathrm{~h}$. Eyes from female Dutchbelted pigmented rabbits (Linköpings Kaninfarm, Sweden) and 9 week old Long-Evans male rats (Envigo, Netherlands) were prepared on site. To sacrifice the lab animals, a lethal dose of 60 $\mathrm{mg} / \mathrm{mL}$ pentobarbital (Mebunat; Orion Pharma, Finland) was injected into the marginal ear vein of the animals. The studies with lab animals were approved by the local animal welfare committee (license \# ESAVI/8621/04.10.07/2017).

Eyes were dissected essentially as before. ${ }^{22}$ Briefly, eyes were kept in ice-cold $1 \times$ DPBS, $\mathrm{pH}$ 7.4. All preparations were performed on ice during the same day. All extraocular parts were removed, and the aqueous humor was aspirated with a 1 $\mathrm{mL}$ syringe $26 \mathrm{G}$ needle. After this, all anterior tissues including conjunctiva, cornea, lens, and iris-ciliary body were separated. From the posterior segment, the vitreous and retina were collected and the RPE layer was scraped using a small brush into $1 \mathrm{~mL}$ of $1 \times$ DPBS. Scraping from the eyecups was done twice to ensure complete collection of the RPE. The RPE suspensions from individual eyes were centrifuged at $6000 \mathrm{~g}$ for 5 min at $+4{ }^{\circ} \mathrm{C}$, and the RPE pellets were pooled. Finally, the choroid and sclera were separated and cleaned from extraocular tissues. Specific tissues from four rabbit or six pig eyes constituted one individual tissue pool, and three such pools were prepared independently. Pooling helped to obtain sufficient material for both enzyme activities and proteomics studies and to decrease interindividual variation among outbred animals. All tissues were stored at $-80{ }^{\circ} \mathrm{C}$ until the day of the homogenate preparation.

CES enzymes are localized in the endoplasmic reticulum, ${ }^{2,45}$ but some activity resides in the cytoplasm. ${ }^{46}$ Therefore, to prevent possible losses during sample preparation, we used whole tissue homogenates to characterize CES expression and activity in ocular tissues. The homogenization of pooled ocular tissues in $1 \times$ DPBS buffer $(3: 1 \mathrm{v} / \mathrm{w})$ was done with a Dounce homogenizer (Thomas Scientific; Swedesboro, NJ) with 5-10 strokes, depending on the ocular tissue. Aqueous humor and vitreous were homogenized without adding buffer. Tissue homogenization buffer was supplemented with protease inhibitor cocktail without phenylmethylsulfonyl fluoride (PMSF), a known inhibitor of esterases. ${ }^{47,48}$ After homogenization, all samples were sonicated at $750 \mathrm{~W}$ (Vibra-Cell VCX50 and a four-element microtip probe; Sonics \& Materials Inc., Newton, CT) using four pulses of $45 \mathrm{~s}$ with a cooling interval of $15 \mathrm{~s}$. After homogenization and sonication, all tissue homogenates were centrifuged at $10000 \mathrm{~g}$ for $15 \mathrm{~min}$ at $+4{ }^{\circ} \mathrm{C}$. Supernatants were collected, aliquoted, and stored at $-80^{\circ} \mathrm{C}$ as whole tissue homogenates. Homogenates for rat whole eye (covered by the license \# ESAVI/8621/04.10.07/2017) and human liver, kindly donated by Prof. Olavi Pelkonen, from Oulu University Hospital, ${ }^{44}$ were also prepared as positive controls for the enzyme assays. Protein quantification of the homogenates was done using the Bradford assay (Bradford, 1976) and bovine serum albumin standard $(0.25-2 \mathrm{mg} / \mathrm{mL})$.

Hydrolysis Assays. 4-Nitrophenol Acetate (NPA) Hydrolysis. NPA hydrolysis was performed with a slight modification to our previous protocol ${ }^{22}$ in clear flat-bottom 96-well Thermo Scientific Sterilin Microtiter plates at $37{ }^{\circ} \mathrm{C}$. Diluted ocular samples ( $8 \mu \mathrm{g}$ of protein in $80 \mu \mathrm{L}$ of PBS) were pipetted into the reaction wells, and the background absorbance was measured at $405 \mathrm{~nm}$ for $10 \mathrm{~min}$ of preincubation. To start the reaction, an equal volume of NPA was added to a final concentration of $400 \mu \mathrm{M}$. Changes in absorbance at $405 \mathrm{~nm}$ were recorded with a Victor ${ }^{2}$ Microplate Reader (PerkinElmer Wallac 1420, St. Paul, MN) for $45 \mathrm{~min}$ with $90 \mathrm{~s}$ reading intervals. 4-Nitrophenol was used to generate a standard curve (5-400 $\mu \mathrm{M})$.

D-Luciferin Methyl Ester (DME) Hydrolysis. The hydrolysis of DME was monitored with slight modifications using the published bioluminescence-based assay ${ }^{13,21}$ where recombinant firefly luciferase enzyme was used to detect the D-luciferin that formed in the reaction mixture. The DME hydrolysis reaction was done in white-coated 96-well plates (Thermo Scientific 
Sterilin Microtiter Plates). Tissue lysates ( $5 \mu \mathrm{g}$ of protein) were preincubated in $0.1 \mathrm{M}$ PBS, $\mathrm{pH}$ 6.5. The reaction was initiated by adding DME to a final concentration of $5 \mu \mathrm{M}$ in a final volume of $200 \mu \mathrm{L}$. The hydrolysis of DME was allowed to proceed for $20 \mathrm{~min}$ at $37^{\circ} \mathrm{C}$. The formed D-luciferin was quantitated by an injection of $73 \mu \mathrm{L}$ of the luciferase detection reagent [ $3 \mu \mathrm{g}$ of rLuciferase, $50 \mathrm{nmol}$ of ATP, and $50 \mathrm{nmol}$ of $\mathrm{MgCl}_{2}$ in PBS], and the luminescence was measured immediately with a Victor ${ }^{2}$ Microplate Reader (560 nm, $1 \mathrm{~s}$ ). Serial 2-fold dilutions of D-luciferin in $0.1 \mathrm{M}$ PBS, $\mathrm{pH} 6.5$ were used to generate the standard curve $(0.156-10 \mu \mathrm{M})$.

Fluorescence Diacetate (FDA) Hydrolysis. A fluorometric assay was used to determine the hydrolysis of FDA to fluorescein. ${ }^{17,49}$ Diluted samples (5 $\mu \mathrm{g}$ of protein) were incubated at $37{ }^{\circ} \mathrm{C}$ in black 96-well Thermo Scientific Nunc F96 MicroWell plates. The background fluorescence was measured with a Victor ${ }^{2}$ Microplate Reader at excitation (485 $\mathrm{nm})$ and emission $(535 \mathrm{~nm})$ for a 5 min preincubation at $37^{\circ} \mathrm{C}$. The reaction was started by adding FDA to a final $100 \mu \mathrm{M}$ concentration to each well in a $200 \mu \mathrm{L}$ total volume. Fluorescence readings were recorded every $60 \mathrm{~s}$ over $30 \mathrm{~min}$. The fluorescein stock solution was used to generate a standard curve $(0.156-10 \mu \mathrm{M})$ using 2-fold serial dilutions in $0.1 \mathrm{M}$ PBS, pH 7.4.

The above assays were optimized for linearity to time and protein concentration in pilot studies, and the final organic solvent content was $0.5 \%(\mathrm{v} / \mathrm{v})$ or less. Specific activities were calculated with the use of the standard curves, rate of the signal change at the linear response range, and the protein concentration. The reaction rates of blank samples (tissue sample replaced by the buffer, substrate replaced by solvent) were measured to control for any nonspecific hydrolysis of the probe substrates and subtracted from sample reaction rates. Three technical replicates were measured for each biological tissue pool, and the mean \pm standard deviation (SD) was calculated.

Quantification of Procaine and Phenacetin Metabolites by LC-MS. Procaine Hydrolysis. Procaine, a known human CES2 substrate, ${ }^{2,17,50}$ was incubated with rabbit and pig ocular tissues. After preincubation of the substrate $(100 \mu \mathrm{M}$ procaine in $0.1 \mathrm{M}$ Tris- $\mathrm{HCl}, \mathrm{pH} 7.4)$ at $37^{\circ} \mathrm{C}$, the reaction was initiated with tissue samples $(20 \mu \mathrm{g}$ of protein) in a total reaction volume of $200 \mu \mathrm{L}$. All the samples in parallel with the controls (no substrate or no enzyme) were incubated for 50 min at $37{ }^{\circ} \mathrm{C}$ on a shaker incubator (Heidolph Titramax 1000 platform shaker, Berlin Germany). The reaction was terminated by adding $200 \mu \mathrm{L}$ of ice-cold ACN containing the internal standard procainamide ( $1 \mu \mathrm{M}$ final concentration), followed by centrifugation at $4{ }^{\circ} \mathrm{C}$ for $10 \mathrm{~min}$ at $10000 \mathrm{~g}$. Supernatants were collected for HPLC analysis. The standard curve was established using the hydrolysis product $\mathrm{PABA}$ with the concentration range $0.1-1000 \mathrm{nM}^{51}$

Phenacetin Hydrolysis. Phenacetin, a specific substrate for human AADAC, ${ }^{18,19,24}$ was incubated with ocular tissue homogenates. The substrate $(4 \mathrm{mM}$, final concentration) was preincubated in the $0.1 \mathrm{M}$ Tris- $\mathrm{HCl}, \mathrm{pH} 7.4$, buffer at $37^{\circ} \mathrm{C}$ for $5 \mathrm{~min}$, after which the tissue samples $(20 \mu \mathrm{g}$ of protein $)$ were added to start the reaction in the total reaction volume of 200 $\mu \mathrm{L}$. All the reaction and control samples were incubated for 50 min at $37{ }^{\circ} \mathrm{C}$ with shaking. The reaction was terminated by adding $200 \mu \mathrm{L}$ of ice-cold ACN containing acetaminophen at an $1 \mu \mathrm{M}$ final concentration as the internal standard, followed by centrifugation at $4{ }^{\circ} \mathrm{C}$ for $10 \mathrm{~min}$ at $10000 \mathrm{~g}$. A standard curve using the metabolite $p$-phenetidine $(0.1-100 \mu \mathrm{M})^{24}$ was established. The protein amount and incubation time were optimized from earlier pilot experiments for both procaine and phenacetin hydrolysis reactions. All incubations were performed in triplicate including the controls (control with no sample, control with no substrate), and the data are expressed as mean $\pm \mathrm{SD}$.

LC/Q Orbitrap MS Analysis. The metabolites from the above CES2 and AADAC assays were analyzed using a Waters (Milford, MA) Acquity ultra-performance liquid chromatographic (UPLC) coupled with a Q-Exactive Focus Orbitrap MS (Thermo Scientific). A Waters HSS T3 column $(2.1 \mathrm{~mm} \times 100$ $\mathrm{mm}, 1.8 \mu \mathrm{m}$ particle size) was used with elution gradients A (0.1\% formic acid) and B (methanol) [0-0.5 min, 1\% B; 0.5-4 min, $1 \%-20 \% \mathrm{~B}$; 4-4.5 min, 20\%-98\% B; 4.5-5 min, 98\% B; and $5-6 \mathrm{~min}, 98 \%-1 \% \mathrm{~B}]$. The injection volume was $2 \mu \mathrm{L}$ with a flow rate of $0.5 \mathrm{~mL} / \mathrm{min}$ and a column temperature of $40{ }^{\circ} \mathrm{C}$. A positive ionization mode with a capillary voltage of $3000 \mathrm{~V}$ and a mass range of $70-1000 \mathrm{~m} / z$ was used. The mass resolution was 35000 (full width at half-maximum @ m/z 200) for a full scan and 17500 for MS/MS in data-dependent acquisition mode. For desolvation and nebulizer, nitrogen gas (sheat gas 40, auxiliary gas 10, and sweep gas 3 arbitrary units) was used, the auxiliary gas temperature was $500{ }^{\circ} \mathrm{C}$, and the capillary temperature was $320{ }^{\circ} \mathrm{C}$. An external calibration system was used, and the data was processed using Thermo Xcalibur (version 4.1.31.9; Thermo Fisher Scientific Inc.). ${ }^{52}$

Estimation of Kinetic and Inhibition Properties. Because of their high hydrolytic activity, corneal and retinal samples from pig and rabbit were used to determine the apparent kinetic parameters Michaelis-Menten constant $\left(K_{\mathrm{m}}\right)$ and maximum reaction velocity $\left(V_{\max }\right)$ for the hydrolysis of NPA, FDA, and DME. At least five different substrate concentrations within the following ranges (NPA 0.1-2 mM; FDA 3-100 $\mu \mathrm{M}$; DME $0.3-10 \mu \mathrm{M}$ ) were used in triplicate using 5-8 $\mu \mathrm{g}$ of protein per well. The inhibition of the NPA, DME, and FDA hydrolytic activities by published esterase inhibitors (PMSF, digitonin, timolol, verapamil, and diltiazem $)^{47,53-55}$ was conducted as described above with the following modifications. Inhibitors were tested at a final concentration range of $0.4-400 \mu \mathrm{M}$ except for PMSF (0.3$2.5 \mathrm{mM})$. The substrate concentrations were reduced to apparent $K_{\mathrm{m}}$ values samples (NPA, $0.1 \mathrm{mM}$; DME, $5 \mu \mathrm{M}$; FDA, $10 \mu \mathrm{M})$. The control samples contained solvent instead of the inhibitor.

In all enzymatic measurements above, negligible hydrolysis rates were observed in the blank sample incubations, which indicated that nonenzymatic hydrolysis is minimal in the present experimental conditions (data not shown).

Targeted Proteomics. In Silico Design of Peptides. Protein sequences were retrieved from the UniProt database (www.uniprot.org/help/uniprotkb). Unique peptide sequences for each protein were designed using BLAST ${ }^{56}$ and CLUSTALW algorithms. ${ }^{57}$ We aimed to use the peptide sequences that were also conserved across multiple species whenever possible. Peptides were selected according to peptide synthesis recommendations. ${ }^{58}$ The peptide for the membrane marker $\mathrm{Na}^{+} / \mathrm{K}^{+}$ATPase was kindly provided by Dr. Mikko Gynther at UEF (Table 2).

Sample Preparation and Trypsin Digestion. The same samples used for enzymatic assays were used for targeted proteomic quantification. For the denaturation, tissue samples (50 $\mu \mathrm{g}$ of protein homogenate) were adjusted to $220 \mu \mathrm{L}$ by 
adding solubilizer ( $7 \mathrm{M}$ guanidine hydrochloride, $3 \mathrm{M}$ Tris- $\mathrm{HCl}$ $\mathrm{pH}$ 8.5, and 0.5 $\mathrm{M} \mathrm{Na}_{2}$-EDTA pH 8.0) in low-protein-binding tubes (Thermo Scientific). Then, an equal volume of DTT was added. The samples were mixed for $60 \mathrm{~min}$ at room temperature in the dark. Thereafter, a 2.5 -fold excess of iodoacetamide was added and incubated for $60 \mathrm{~min}$ at room temperature in the dark to alkylate the sulfhydryl groups. For protein precipitation, the samples were cooled on ice and icecold methanol $(600 \mu \mathrm{L})$, chloroform $(150 \mu \mathrm{L})$, and deionized water $(450 \mu \mathrm{L})$ were added sequentially with mixing by inversion. Tubes were centrifuged at $15000 \mathrm{~g}$ for $5 \mathrm{~min}$ at +4 ${ }^{\circ} \mathrm{C}$. The upper layer containing lipids was discarded, and the samples were washed twice by ice-cold methanol $(450 \mu \mathrm{L})$. The remaining protein pellets were resuspended by adding $6 \mathrm{M}$ urea $(9 \mu \mathrm{L})$ and $0.1 \mathrm{M}$ Tris- $\mathrm{HCl}(36.5 \mu \mathrm{L})$ and mixing for $10 \mathrm{~min}$ at room temperature.

To ensure complete resuspension, intermittent sonication was done (30 s per cycle: Branson 2510) while keeping samples on ice. For the protein digestion, $0.5 \mu \mathrm{g}$ of LysC (1/100-fold of protein amount) and proteaseMax (final concentration $0.05 \%$ ) were added to the samples processed above. Subsequently, 0.15 pmol of heavy-labeled peptides (Table 2) were added to each $50 \mu \mathrm{g}$ protein sample tube and incubated for $3 \mathrm{~h}$ at $37^{\circ} \mathrm{C}$.

Thereafter, TPCK-treated trypsin $(0.5 \mu \mathrm{g})$ was added to each tube and incubated overnight at $37{ }^{\circ} \mathrm{C}$. The digestion was terminated by adding $3 \mu \mathrm{L}$ of $20 \%$ formic acid per sample, followed by centrifugation at $15000 \mathrm{~g}$ at $+4{ }^{\circ} \mathrm{C}$. The supernatants were transferred to fresh vials, and an aliquot corresponding to $22.7 \mu \mathrm{g}$ of original protein homogenate from each digest was taken for targeted quantitative proteomic analysis. The digests were treated with SPE (C18, $10 \mathrm{mg} / \mathrm{mL}$ cartridges) in preparation for nanoLC-MS/MS analysis. Cartridges were conditioned with $250 \mu \mathrm{L}$ of methanol followed by $250 \mu \mathrm{L}$ of deionized water. A sample was added, and the cartridges were washed with $150 \mu \mathrm{L}$ of deionized water. Peptides were eluted with $250 \mu \mathrm{L}$ of $\mathrm{ACN} / 0.1 \%$ formic acid (60/40) into $0.5 \mathrm{~mL}$ LoBind Eppendorf tubes. Samples were then evaporated to dryness and reconstituted in $50 \mu \mathrm{L}$ of $2 \%$ $\mathrm{ACN}$. The samples were centrifuged at $13400 \mathrm{~g}$ for $5 \mathrm{~min}$, and the supernatants were transferred to deactivated vial inserts for analysis.

Targeted Quantitative Analysis with NanoLC-MS/ MS. The analysis was performed as previously described ${ }^{59,60}$ on a nanoAcquity (Waters) coupled to a QTRAP 5500 with a NanoSpray III source (SCIEX, Framingham, MA). The system control was with nanoAcquity UPLC Console software (Waters) and Analyst 1.5 (SCIEX). The mobile phase was as follows: A, $1 \% \mathrm{ACN}$ and $0.1 \%$ formic acid in deionized water and $\mathrm{B}, 100 \% \mathrm{ACN}$. The injection volume was $0.2 \mu \mathrm{L}$ corresponding to $0.091 \mu \mathrm{g}$ of sample or $0.4 \%$ of the nominal sample amount $(22.7 \mu \mathrm{g})$. A sample was loaded onto a Symmetry C18 trap column (Waters, part \# 186006527, $5 \mu \mathrm{m}$ particle size, $180 \mu \mathrm{m} \times 20 \mathrm{~mm}$ ). The trapping flow was $15 \mu \mathrm{L} /$ min of mobile phase A for $1 \mathrm{~min}$. The analytical column was a $\mathrm{BEH} 130 \mathrm{C} 18,1.7 \mu \mathrm{m}$ particle size, $150 \mathrm{~mm} \times 100 \mathrm{~mm}$ (Waters, part \# 186003550). The flow rate was $1.3 \mu \mathrm{L} / \mathrm{min}$, and the gradient is shown in Table $\mathrm{S} 1$, with the total run time being 35 min. The mass spectrometer was operated in the positive mode with the ion spray voltage set at 4000. A $90 \mathrm{~s}$ scheduled acquisition window was used for each peptide. For a selection of multiple reaction monitoring (MRM) transitions to be used (two labeled and two unlabeled per peptide), a range of transitions were first predicted by Skyline software (version 2.6,
University of Washington). The five transitions giving the highest response for SIL peptide standards were selected, and the collision energies were optimized by repeated injection onto the system (declustering potentials were left unchanged). The two MRMs giving the best response were then selected for use in concentration calculations. MRM data was processed using MultiQuant 2.0.2 (SCIEX). Peptide concentrations were calculated using area ratios of endogenous (unlabeled) to a known amount of SIL peptide standard $(0.15 \mathrm{pmol}$ to the initial $50 \mu \mathrm{g}$ of protein). Equality of response between the SIL and unlabeled peptides was assumed. One peptide, generally that giving the highest value, was used to report the concentration of the relevant protein with a second peptide, if available, being used as confirmatory.

Statistical Analysis. The differences among hydrolytic activities were analyzed by ANOVA using the SigmaPlot software (Sigma Plot 13.0, Systat Software Inc., San Jose, CA), followed by Mann-Whitney U test for statistical comparisons between species and between tissues. Between species, statistically significant differences are ranked by the asterisk signs (in the order of *, $p<0.05$; **, $p<0.01$, and *** $p<$ 0.001 ). Between tissues of the same species, statistically significant differences in comparison to conjunctiva are represented by the dagger sign ( $\dagger, p<0.05)$. Nonlinear regression analysis to determine the $K_{\mathrm{m}}, V_{\max }$ and $\mathrm{IC}_{50}$ values were done using GraphPad Prism (GraphPad, 5.04 Software Inc., San Diego, CA). For $\mathrm{IC}_{50}$, logarithms of inhibitor concentrations were plotted against the relative response $(0$ $\mu \mathrm{M}$ inhibitor $=100 \%)$.

\section{RESULTS}

NPA, DME, and FDA Hydrolytic Activities. NPA is often used to measure the activities of various hydrolytic enzymes including CESs, $\mathrm{AADAC}$, acetylcholinesterase, and arylesterase in multiple species. ${ }^{2,22,23,61}$ The positive controls, rat whole eye and human liver homogenates, showed high rates of NPA hydrolysis (Figure 1A) as expected from the literature. ${ }^{22,40,61}$ Rabbit samples showed quite similar rates of $30-45 \mathrm{nmol} / \mathrm{min} /$ $\mathrm{mg}$ protein for NPA hydrolysis among most tissue homogenates, while the lowest activity was observed in RPE $(17.5 \pm 2.7$ $\mathrm{nmol} / \mathrm{min} / \mathrm{mg}$ ) and the highest in the choroid $(81.6 \pm 6.8$ $\mathrm{nmol} / \mathrm{min} / \mathrm{mg}$ ). For the pig, NPA hydrolysis rates were very similar, around $20 \mathrm{nmol} / \mathrm{min} / \mathrm{mg}$ among all tissues, except the lowest rate was observed again with RPE $(8.4 \pm 1.0 \mathrm{nmol} / \mathrm{min} /$ $\mathrm{mg}$ ).

Overall, the enzymatic activities in pig tissues tended to be lower than those in the rabbit, corresponding to earlier data, ${ }^{22}$ and statistically significant species differences were noted for the cornea, aqueous humor, and choroid.

DME has been suggested as a highly selective and sensitive substrate for detecting CES1 activity in the human liver. ${ }^{13}$ To date, there are no reports on DME hydrolytic activities in ocular tissues or in other rabbit or porcine tissues. Control samples showed the hydrolysis rates for human liver and rat whole eye homogenate at $3.6 \pm 0.7$ and $2.6 \pm 0.2 \mathrm{nmol} / \mathrm{min} / \mathrm{mg}$, respectively (Figure $1 \mathrm{~A}$ ). In rabbit ocular tissues, hydrolysis rates were high $(\geq 1 \mathrm{nmol} / \mathrm{min} / \mathrm{mg})$ in the conjunctiva, cornea, and choroid, moderate $(0.5-1.0 \mathrm{nmol} / \mathrm{min} / \mathrm{mg})$ in the aqueous humor and vitreous, and low $(0.1-0.5 \mathrm{nmol} / \mathrm{min} /$ $\mathrm{mg}$ ) in the RPE and retina (Figure 1B). Similarly, in pig, DME hydrolysis was high $(\geq 1 \mathrm{nmol} / \mathrm{min} / \mathrm{mg})$ in the conjunctiva, cornea, and choroid, more moderate (about $0.5-1 \mathrm{nmol} / \mathrm{min} /$ $\mathrm{mg})$ in the retina, and relatively low $(0.1-0.2 \mathrm{nmol} / \mathrm{min} / \mathrm{mg})$ 


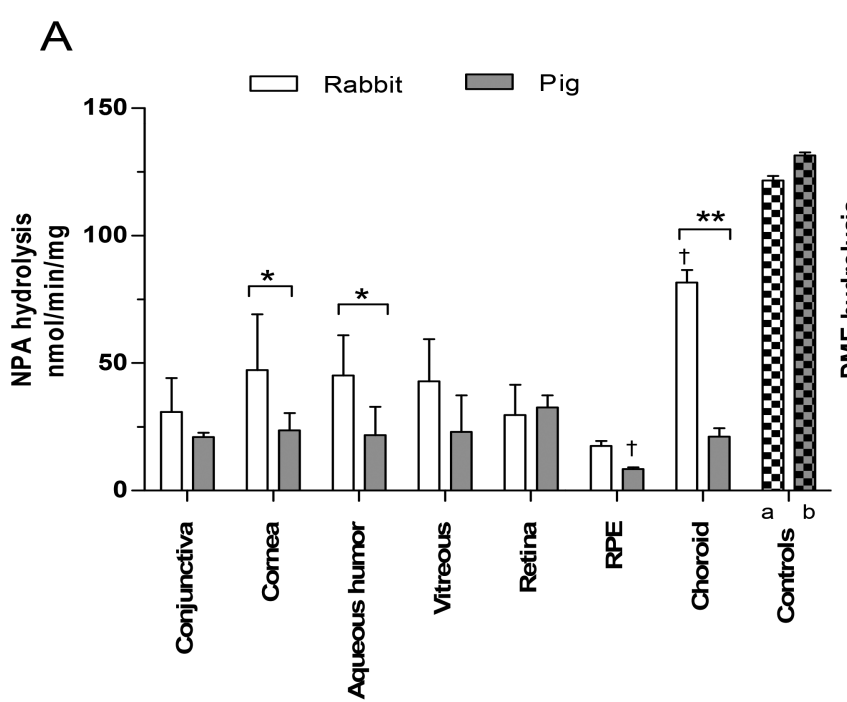

B

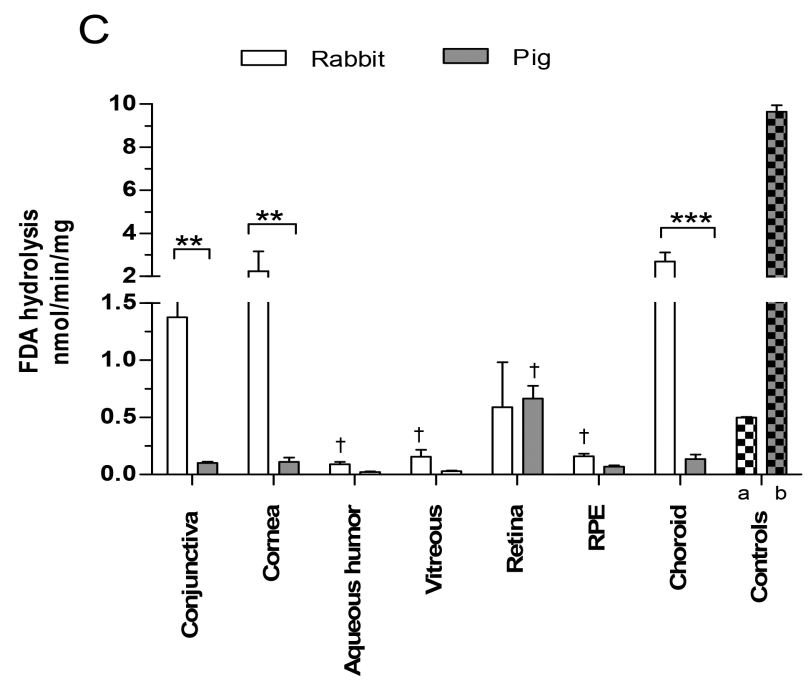

Figure 1. Hydrolysis of (A) NPA, (B) DME, and (C) FDA in ocular tissue samples from pigmented rabbits (white columns), pig (gray columns), and positive controls (patterned columns; $\mathrm{a}=$ rat whole eye homogenate, $\mathrm{b}=$ human liver homogenate). The data shown are mean \pm SD from three different pools, each measured in three technical replicates. Statistical comparisons between species $(*)$ and between tissues in the same species as compared to conjunctiva $(\dagger)$ were done by the Mann-Whitney nonparametric test. Statistically significant differences are ranked as follows: $* \dagger, p<$ $0.05, * *, p<0.01, * * * p<0.001$.

in the RPE, aqueous humor, and vitreous (Figure 1B). Statistically significant species differences were noted for aqueous humor and vitreous, which had about 5-10-fold higher activity in the rabbit than in the pig.

FDA has been indicated as a probe substrate for the determination of CES2 activity in human liver ${ }^{17,49}$ while its hydrolysis has not been studied so far in ocular tissues or in rabbit or porcine tissues. Rabbit tissues showed (Figure 1C) high hydrolysis rates $(>1.0 \mathrm{nmol} / \mathrm{min} / \mathrm{mg})$ in the choroid, cornea, and conjunctiva as compared to other tissues (retina, $0.5-1 \mathrm{nmol} / \mathrm{min} / \mathrm{mg}$; RPE, aqueous humor and vitreous, $0.1-$ $0.2 \mathrm{nmol} / \mathrm{min} / \mathrm{mg}$ ). FDA hydrolysis was remarkably low in most pig ocular tissues $(<0.1 \mathrm{nmol} / \mathrm{min} / \mathrm{mg})$ except retinal samples $(0.6 \pm 0.1 \mathrm{nmol} / \mathrm{min} / \mathrm{mg})$. Much higher hydrolysis rates (up to 20-fold) were seen in most rabbit ocular tissues as compared to porcine tissues (Figure 1C), and cornea, choroid, and conjunctiva showed statistically significant species differences.

Procaine and Phenacetin Hydrolysis. The presence of CES2 in ocular tissues was also probed by measuring the formation of human CES2-selective metabolite PABA from procaine. ${ }^{50,51}$ Rabbit ocular tissues showed PABA formation in all tissues (Figure 2). The activities were rather similar in the cornea, vitreous, $\mathrm{RPE}$, and choroid $(\sim 0.2-0.3 \mathrm{nmol} / \mathrm{min} / \mathrm{mg})$ while the aqueous humor and conjunctiva displayed 4-7-fold lower levels $(\sim 0.04-0.1 \mathrm{nmol} / \mathrm{min} / \mathrm{mg})$. In contrast, the pig ocular tissues showed more evenly distributed procaine hydrolysis rates in all tissues, ranging from the lowest in aqueous humor $(0.02 \mathrm{nmol} / \mathrm{min} / \mathrm{mg})$ to the highest in the retina $(0.09 \mathrm{nmol} / \mathrm{min} / \mathrm{mg})$. Rabbit tissues tended to contain higher rates of PABA formation as compared to pig tissues, similarly to FDA hydrolysis.

Phenacetin is hydrolyzed to $p$-phenetidine by the human AADAC. ${ }^{24}$ However, the levels of $p$-phenetidine formed in the incubation from the ocular tissue of rabbit and pig were below the detection limit $(\sim 0.1 \mathrm{pmol} / \mathrm{min} / \mathrm{mg})$ in the present experimental conditions (data not shown). The positive control samples showed significant activities as expected.

Kinetics and Inhibition Studies. Kinetic parameters for NPA, DME, and FDA hydrolysis were determined in pig and 


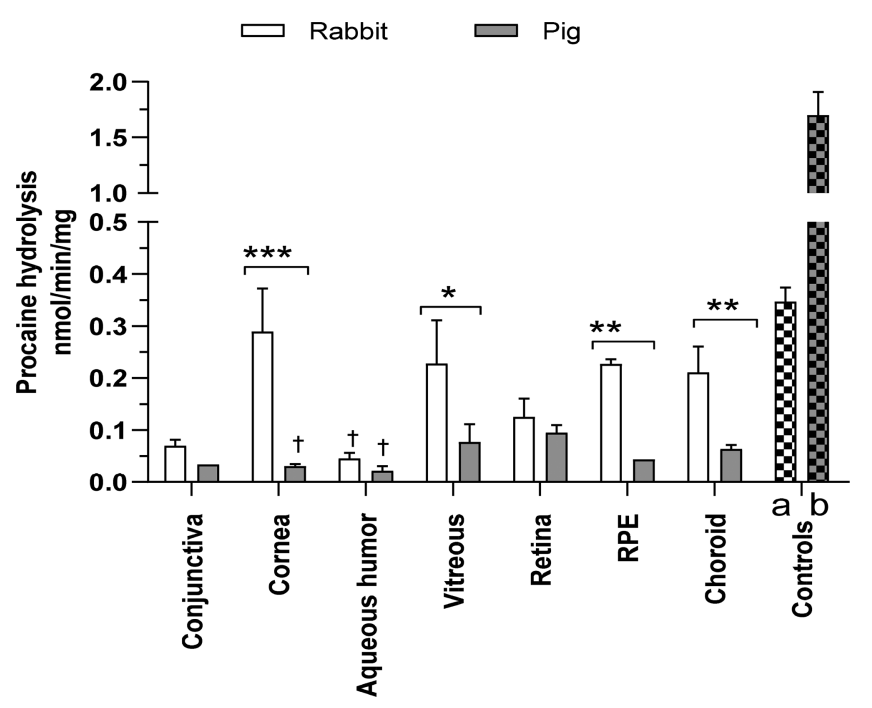

Figure 2. Hydrolysis of procaine to PABA in ocular tissues (conjunctiva, cornea, aqueous humor, vitreous, retina, RPE, and choroid) of rabbit (light gray) and pig (dark gray). The data shown are mean $\pm S D$ from three different pools, each measured in three technical replicates. Statistical comparisons between species $(*)$ and between tissues in the same species as compared to vitreous $(\dagger)$ were done by Mann-Whitney nonparametric test. Statistically significant differences are ranked as follows: $*, p<0.05, * *, p<0.01$, *** $p<$ 0.001 .

rabbit corneal and retinal tissues and compared to the existing literature (Table 3 and Figure 1). For all three substrates, the observed $K_{\mathrm{m}}$ values were within 4 -fold or less of the reported values employing different human enzyme sources (Table 3). Unfortunately, there is only limited published data on pig liver CES1 and rabbit corneal CESs with NPA. Given the overall similarity of the $K_{\mathrm{m}}$ values across different species and tissues, we judged that they were sufficiently accurate to select substrate concentrations for the subsequent inhibition studies.

Inhibition studies were conducted first with the general esterase substrate NPA to validate the hydrolysis assays (Table 4). PMSF, a generic hydrolase inhibitor, inhibited NPA hydrolysis in pig cornea rather gradually to the maximum of about $80 \%$ at the highest concentration. A unique $\mathrm{IC}_{50}$ value could not be determined, but a 50\% inhibition was observed at about $200 \mu \mathrm{M}$ (Figure 2). Under the present experimental conditions, timolol and diltiazem could not appreciably inhibit NPA hydrolysis (maximal inhibition of $10 \%$ and $20 \%$ at the highest $400 \mu \mathrm{M}$ concentration). The human CES1-selective inhibitor digitonin showed significant inhibition of NPA hydrolysis $(\sim 40 \%)$ and a quantifiable IC $_{50}$ value $(38 \pm 3 \mu \mathrm{M})$.
Digitonin was also used to inhibit DME hydrolysis in pig and rabbit tissues with high DME activity. In rabbit conjunctiva, digitonin showed no inhibition in DME hydrolysis, while a slight $15 \%$ inhibition was observed in pig conjunctiva (Figure $3 \mathrm{~A}, \mathrm{~B})$. In pig and rabbit cornea, digitonin showed slightly stronger maximal inhibitions of $45 \%$ and $30 \%$, respectively (Figure 3C,D). Rabbit and pig retina that showed relatively high FDA activities were used to inhibit FDA hydrolysis using a human CES2-selective inhibitor verapamil and timolol. No inhibition of FDA hydrolysis was seen in pig retina for either inhibitor (Figure 4A,B). However, about $40 \%$ inhibition of FDA hydrolysis was evident in rabbit retina with verapamil but less with timolol (Figure 4C,D). These data suggest that pig and rabbit CES enzymes are somewhat affected by human CES inhibitors, but the less than complete inhibition suggests that multiple enzymes participate in the hydrolysis of these substrates.

Quantification of Protein Expression. Considering the reference samples, the human liver homogenate displayed a higher expression of CES1 $(64 \pm 8 \mathrm{pmol} / \mathrm{mg})$ as compared to that of CES2 $(30.6 \pm 2.1 \mathrm{pmol} / \mathrm{mg})$, as expected from a recent report, ${ }^{65}$ while the expression of CES3 was very low $(\sim 0.2$ $\mathrm{pmol} / \mathrm{mg})$. We report here for the first time that the expression of CES1 $(\sim 3.0 \mathrm{pmol} / \mathrm{mg})$ and CES3 $(\sim 2.3 \mathrm{pmol} / \mathrm{mg})$ proteins was higher than CES2 levels $(\sim 0.2 \mathrm{pmol} / \mathrm{mg})$ in rat whole eye. In rabbit ocular samples, a relatively low and even expression of CES1 $(\sim 0.2 \mathrm{pmol} / \mathrm{mg})$ was seen in all tissues except conjunctiva and choroid. CES2 was present in rabbit conjunctiva, retina, and choroid $(0.3,0.2$, and $0.1 \mathrm{pmol} / \mathrm{mg}$, respectively), while other tissue levels were below the lower limit of quantitation (LLOQ $0.1 \mathrm{pmol} / \mathrm{mg}$ protein).

Pig cornea showed the highest expression of CES1 $(8.0 \pm 2.5$ $\mathrm{pmol} / \mathrm{mg}$ ), while the expression was clearly detectable in choroid and conjunctiva $(\sim 0.7 \mathrm{pmol} / \mathrm{mg})$, followed by vitreous $(\sim 0.2 \mathrm{pmol} / \mathrm{mg})$, and all other pig tissues were below the LLOQ. CES2, in accordance with its absence in the pig genome (UCSC Genome Browser assembly ID: susScr11), was not measured in the pig tissues. Finally, CES3 showed no or very low expression in rabbit or pig tissues, respectively, and AADAC seemed to be absent in the ocular tissues of both species (Table 5) in contrast to their presence in the reference samples. ${ }^{56}$ Thus, there were clear species differences in the expression of CES1 and CES2. CES1 was expressed at higher levels in pig tissues as compared to the rabbit, apart from retina and RPE where the situation was the opposite. CES2 was found in the rabbit ocular tissues and is not believed to be present in pig due to the absent CES2 gene.

The $\mathrm{Na}^{+} / \mathrm{K}^{+}$ATPase is a membrane-bound marker ${ }^{58,66}$ that was used to indicate the enrichment of membrane fraction in the samples. In both rabbit and pig ocular tissues, retina and

Table 3. Kinetics for CES Mediated Hydrolysis Reactions

\begin{tabular}{clll} 
substrate & \multicolumn{1}{c}{ main enzyme } & \multicolumn{1}{c}{$K_{\mathrm{m}}(\mu \mathrm{M})$ literature data } & \multicolumn{1}{c}{ references } \\
NPA & multiple esterases & $198 \pm 17(\mathrm{HLM})^{a}$ & $23,32,49$, and 62 \\
& & $68 \pm 15($ rabbit cornea $)$ \\
DME & CES1 & $520 \pm 60($ pig liver CES1) & \\
& & $\approx 5($ rhCES1) & 13 \\
FDA & CES2 & $4.87 \pm 0.51(\mathrm{HLM})$ & 16,49 , and 63
\end{tabular}

${ }^{a}$ HLM, human liver microsomes; rhCES, recombinant human CES1 or CES2. 
Table 4. Inhibition for CES Mediated Hydrolysis Reactions ${ }^{a}$

\begin{tabular}{|c|c|c|c|c|c|}
\hline inhibitor & $\begin{array}{l}\text { main human } \\
\text { enzyme }\end{array}$ & $\mathrm{IC}_{50}$ & $K_{\mathrm{i}}$ & references & $\mathrm{IC}_{50}$ or extent of inhibition (this study) \\
\hline PMSF & most esterases & $0.541 \mathrm{mM}$ & $0.56 \mathrm{mM}$ & $\begin{array}{l}47,48 \\
\text { and } 53\end{array}$ & NPA: $\sim 200 \mu \mathrm{M}$ in pig cornea \\
\hline \multirow[t]{2}{*}{ digitonin } & CES1 & $9.2 \pm 0.4 \mu \mathrm{M}(\mathrm{rhCES} 1)$ & NA & 53 and 54 & NPA: $38 \pm 3 \mu \mathrm{M}$ in pig cornea \\
\hline & & $25.8 \mu \mathrm{M}(\mathrm{rhCES} 1)$ & & & $\begin{array}{l}\text { DME: }>200 \mu \mathrm{M} \text { in pig cornea, } \sim 30 \% \text { at } 200 \mu \mathrm{M} \text { in } \\
\text { rabbit cornea, }<20 \% \text { in both conjunctivas }\end{array}$ \\
\hline \multirow[t]{2}{*}{ timolol } & CES2 & $20 \%$ inhibition at $200 \mu \mathrm{M}$ & NA & $\begin{array}{l}2,53 \text {, and } \\
54\end{array}$ & NPA: no inhibition in pig cornea \\
\hline & & & & & $\begin{array}{l}\text { FDA: }<20 \% \text { inhibition in rabbit retina, no inhibition in } \\
\text { pig retina }\end{array}$ \\
\hline \multirow[t]{2}{*}{ verapamil } & $\mathrm{CES} 2>\mathrm{CES} 1$ & $7.94 \mu \mathrm{M}(\mathrm{rhCES} 2)$ & $11.5 \pm 1.20 \mu \mathrm{M}(\mathrm{HLM})$ & $\begin{array}{l}20,53 \\
\text { and } 64\end{array}$ & NPA: $28 \pm 7 \mu \mathrm{M}$ in pig cornea; \\
\hline & & & $3.84 \pm 0.99 \mu \mathrm{M}(\mathrm{rhCES} 2)$ & & $\begin{array}{l}\text { FDA: } 38 \pm 8 \mu \mathrm{M} \text { in rabbit retina, no inhibition in pig } \\
\text { retina }\end{array}$ \\
\hline diltiazem & $\mathrm{CES} 2>\mathrm{CES} 1$ & $3.98 \mu \mathrm{M}(\mathrm{rhCES} 2)$ & $2.89 \pm 0.39 \mu \mathrm{M}(\mathrm{HLM})$ & $\begin{array}{l}20,53 \\
\text { and } 64\end{array}$ & NPA: no inhibition in pig cornea \\
\hline
\end{tabular}

${ }^{a}$ HLM, human liver microsomes; NA, not available; rhCES, recombinant human CES1 or CES2. Inhibition of substrate hydrolysis was done in pig cornea for NPA, in pig and rabbit cornea and conjunctiva for DME, and in pig and rabbit retina for FDA.

Table 5. Concentrations of CESs and AADAC Proteins Determined in Rabbit and Pig Ocular Tissues ${ }^{a}$

\begin{tabular}{|c|c|c|c|c|c|c|c|c|c|c|}
\hline \multirow[b]{2}{*}{ enzyme } & \multirow[b]{2}{*}{ species } & \multicolumn{7}{|c|}{ ocular tissues ( $\mathrm{pmol} / \mathrm{mg}$ protein) } & \multicolumn{2}{|c|}{$\begin{array}{l}\text { reference samples }(\mathrm{pmol} / \mathrm{mg} \\
\text { protein) }\end{array}$} \\
\hline & & conjunctiva & cornea & aqueous humor & vitreous & retina & RPE & choroid & rat whole eye & human liver \\
\hline \multirow[t]{2}{*}{ CES1 } & rabbit & $<$ LLOD & $0.14 \pm 0.05$ & $0.1 \pm 0.03$ & $0.2 \pm 0.01$ & $0.2 \pm 0.03$ & $0.1 \pm 0.02$ & $<$ LLOD & $3.0 \pm 0.1$ & $64 \pm 8.0$ \\
\hline & pig & $0.7 \pm 0.1$ & $8.05 \pm 2.5$ & $<$ LLOD & $0.2 \pm 0.01$ & $<\mathrm{LLOQ}^{*}$ & $<$ LLOD & $0.7 \pm 0.2$ & & \\
\hline \multirow[t]{2}{*}{ CES2 } & rabbit & $0.3 \pm 0.1$ & $<$ LLOQ* $^{*}$ & $<$ LLOD & $<$ LLOD & $0.2 \pm 0.1$ & $<$ LLOD & $0.1 \pm 0.07$ & $0.2 \pm 0.05$ & $30.6 \pm 2.1$ \\
\hline & pig & ND & ND & ND & ND & $\mathrm{ND}$ & ND & ND & & \\
\hline \multirow[t]{2}{*}{ CES3 } & rabbit & $<$ LLOD & $<$ LLOD & $<$ LLOD & $<$ LLOD & $<$ LLOD & $<$ LLOD & $<$ LLOD & $2.3 \pm 0.1$ & $0.2 \pm 0.09$ \\
\hline & pig & $<$ LLOD & $0.1 \pm 0.01$ & $<$ LLOD & $<$ LLOD & $<$ LLOD & $<$ LLOQ* $^{*}$ & $<$ LLOD & & \\
\hline \multirow[t]{2}{*}{ AADAC } & rabbit & $<$ LLOD & $<$ LLOD & $<$ LLOD & $<$ LLOD & $<$ LLOD & $<$ LLOD & $<$ LLOD & $0.3 \pm 0.01$ & $0.8 \pm 0.2$ \\
\hline & pig & $<$ LLOD & $<$ LLOD & $<$ LLOD & $<$ LLOD & $<$ LLOD & $<$ LLOD & $<$ LLOD & & \\
\hline \multirow[t]{2}{*}{$\mathrm{Na}^{+} / \mathrm{K}^{+}$ATPase } & rabbit & $1.5 \pm 0.3$ & $1.4 \pm 0.7$ & $<$ LLOD & $1.1 \pm 0.3$ & $10.3 \pm 1.3$ & $6.0 \pm 2.5$ & $4.5 \pm 1.3$ & $1.5 \pm 0.3$ & $2.7 \pm 0.2$ \\
\hline & pig & $1.3 \pm 0.1$ & $1.4 \pm 0.2$ & $<$ LLOD & $0.3 \pm 0.1$ & $17 \pm 7.5$ & $7.0 \pm 1.7$ & $4.0 \pm 1.2$ & & \\
\hline
\end{tabular}

${ }^{a}$ LLOD, lower limit of detection $=3 \times$ signal/noise ratio; LLOQ lower limit of quantification $=0.1 \mathrm{pmol} / \mathrm{mg}$ protein; * protein detectable but not quantifiable; ND, not done, due to absence of the CES2 gene. The protein expression levels of CES1, CES2, CES3, and AADAC were determined in the rabbit and pig ocular tissues. $\mathrm{Na}^{+} / \mathrm{K}^{+}$ATPase served as a marker for the membrane fraction. Each data point calculated in pmol/mg presented above is the average of three pools \pm SD.

RPE exhibited abundant expression (6-17 pmol/mg), followed by choroid $(\sim 4.5 \mathrm{pmol} / \mathrm{mg})$, cornea, and conjunctiva $(\sim 1.3$ $\mathrm{pmol} / \mathrm{mg}$ ). The relatively cell-free aqueous humor and vitreous had no or little $\mathrm{Na}^{+} / \mathrm{K}^{+}$ATPase expression as expected. This suggests a similar efficiency of protein extraction between all samples.

Correlation between the Enzyme Activity and Protein Expression. Rabbit ocular tissues showed no significant correlation between the human CES1-related DME activity and the quantity of CES1 protein (Figure $5 \mathrm{~A}$ ). In addition, the selective human CES1-selective inhibitor digitonin attenuated DME hydrolysis only by $30 \%$ in rabbit cornea or less in conjunctiva (Table 4 and Figure 3 ). On the contrary, a significant positive correlation $\left(r^{2}=0.803\right)$ was observed between DME activity and CES1 content in pig ocular tissues (Figure 5B). We also observed that the extent of DME inhibition by digitonin in pig conjunctiva and cornea was stronger than that in the rabbit (Table 4 and Figure 3) and correlated with CES1 contents in these pig tissues.

No correlation was observed between the FDA activity and CES2 quantity in rabbit ocular tissues (Figure 5C), although the human CES2-selective inhibitor verapamil reduced FDA hydrolysis significantly in rabbit retina (Table 4 and Figure 4), the tissue with highest CES1 content. For the pig, the CES2 gene is absent and thus no correlation could be established. In line with the absence of CES2, neither verapamil or another human CES2 inhibitor timolol blocked FDA activity in pig retina, indicating that another hydrolase is responsible for this activity. However, FDA and procaine hydrolysis, often used to determine human CES2-dependent activity, correlated strongly $\left(r^{2}=0.810\right)$ in pig ocular tissues but poorly in rabbit tissues (Figure 4D,E). Finally, the emerging esterase AADAC was included in proteomics and enzymatic assays; the results indicated negligible expression and activity of AADAC in ocular tissues of both species.

\section{DISCUSSION}

Ocular drug metabolism is still poorly defined. Knowledge on the presence and levels of drug-metabolizing enzymes in ocular tissues would be essential to aid in ophthalmic drug development and delivery. We aimed to generate data on the drug-metabolizing capacity of hydrolyzing enzymes in ocular tissues of rabbits and pigs, which are commonly employed preclinical species for ocular drug development. Numerous ocular drugs or prodrugs containing an ester or amide bond are liable to hydrolysis in ocular tissues of various species. ${ }^{33,38,61,67}$ 
Although esterase activity is well-presented, the detailed activity and expression data on CES isoforms in the eye is still ambiguous. ${ }^{22,40}$ For the first time in ocular tissues, we adopted substrates and inhibitors that have been used to characterize human $\mathrm{CES}^{13,16,25}$ and $\mathrm{AADAC}^{18,21}$ activities, because the respective rabbit and pig enzymes have not been expressed in vitro and characterized for their substrate specificity. To our knowledge, there are no earlier reports on the quantitative protein expression of these enzymes in rabbit and pig ocular tissues. The accumulation of such information will help design experiments in ocular drug metabolism and aid in the interpretation of resulting data. Detailed knowledge of esterase expression will assist in evaluating the feasibility of an esterasedependent prodrug approach, the design of esterase-cleavable drug conjugates for ocular drug therapy, and the extent of ocular effects of systemically administered drugs that are substrates for hydrolytic enzymes. The species differences in ocular drug hydrolysis also affect the design and interpretation of translational and toxicity studies.

The hydrolysis of the general hydrolase substrate, NPA, has been detected in ocular tissues of multiple species including pig and rabbit. ${ }^{22,40,61}$ In a recent study ${ }^{22}$ from our laboratory, most of the pig and albino rabbit ocular tissues displayed very similar rates of NPA hydrolysis as what we report here. The only exceptions were pig aqueous humor and rabbit choroid, with slightly higher (30\%) specific activities in the present study. These modest differences are explained by our fully optimized reaction conditions and a pigmented rabbit strain used here. A similar study was earlier conducted with a naphthyl prodrug to determine esterase hydrolysis in the anterior eye segment. The relative hydrolysis rates of naphthyl prodrugs were similar to those of our study (cornea $>$ conjunctiva $>$ aqueous humor). Again, pigmented rabbits showed $10 \%-100 \%$ higher esterase activity as compared to albino animals. ${ }^{8,40,61}$

In addition to this, dipivalyl epinephrine, an ester prodrug showed a twice as large hydrolysis rate in the corneal epithelium of pigmented rabbit as that seen in albinos. ${ }^{33}$ A ganciclovir ester prodrug was hydrolyzed in descending order of reaction rate in choroid, retina, and vitreous homogenates, a pattern similar to that of NPA hydrolysis in our study. ${ }^{37,38}$ Similarly, loteprednol etabonate was hydrolyzed more rapidly in rabbit cornea than in aqueous humor. ${ }^{39}$ Likewise, topically applied latanoprost, an ester prodrug, showed complete hydrolysis in rabbit cornea. ${ }^{34}$ In summary, across all studies, the cornea appeared to have the highest and the vitreous and aqueous humor had the lowest hydrolytic activities for different ester substrates. However, the isoforms responsible for these reactions remain unknown.

To the best of our knowledge, scant literature is available on the inhibition of ocular carboxylesterases. Lee reported 30\%$70 \%$ inhibition of naphthyl acetate hydrolysis in rabbit cornea, iris-ciliary body, and aqueous humor by several cholinesterase inhibitors at $1000 \mu \mathrm{M}$ while $p$-chloromercuribenzoate and EDTA, which are inhibitors of carboxylesterase and arylesterase, respectively, blocked the hydrolysis only by $10 \%-30 \%{ }^{61}$ Our inhibition analysis showed that the generic esterase inhibitor PMSF blocked the NPA hydrolysis by more than $80 \%$ in pig cornea. Although a unique $\mathrm{IC}_{50}$ value could not be determined, $50 \%$ inhibition was reached at $\sim 200 \mu \mathrm{M}$, which is rather close to the reported $\mathrm{IC}_{50}$ value of $\sim 500 \mu \mathrm{M}$ in other tissues. $^{47,48}$ The selective human CES1 inhibitor digitonin ${ }^{53}$ inhibited NPA hydrolysis in pig cornea by about $40 \%$, while timolol or diltiazem had little if any effect. Verapamil has been reported to inhibit CES2 20,53 or both CES1 and CES2, ${ }^{64}$ and it significantly blocked pig corneal NPA hydrolysis. Although additional enzymes likely contributed to the hydrolysis of NPA, these findings seem consistent with the higher expression of CES1 enzyme in pig cornea that leads to substantial CES1 inhibition by digitonin and verapamil. The lack of inhibition by timolol or diltiazem is in line with negligible CES2 expression in pig cornea.

The human CES1-selective substrate $\mathrm{DME}^{13}$ was hydrolyzed at the highest rates in rabbit and pig conjunctiva, cornea, and choroid. However, there was a poor correlation between the DME activity and CES1 content in rabbit tissues. On the contrary, the extent of DME inhibition by digitonin was greater (30\%) in rabbit cornea that expressed the CES1 protein than in conjunctiva lacking CES1. In contrast, DME activity and CES1 content correlated in pig. This finding is well supported by the inhibition of DME hydrolysis, where digitonin showed a stronger inhibitory effect in pig than in rabbit tissues. The rates of human CES2-selective FDA hydrolysis were the highest in the rabbit conjunctiva, cornea, and choroid. Again, no correlation between FDA hydrolysis and CES2 content was found in rabbit tissues. This hypothesis was supported by the fact that no inhibition was shown in FDA hydrolysis by verapamil. Poor correlations between hydrolysis rates of DME or FDA substrates and CES1 or CES2 contents, respectively, and less than complete blockade by inhibitors both suggest that other hydrolytic enzymes in the rabbit ocular tissues contribute to the metabolism of these human-selective substrates.

FDA has been suggested as a human CES2-specific substrate, ${ }^{17,49}$ but later studies revealed that it is also hydrolyzed by human AADAC. ${ }^{14,16}$ Subsequently, we determined the hydrolysis of procaine, a more specific substrate for human CES2, ${ }^{50}$ and of phenacetin for AADAC. ${ }^{19,24}$ Rabbit ocular tissues showed a much higher activity for FDA and procaine than the pig, which is in line with the lack of CES2 in the latter species, while both AADAC content and phenacetin hydrolysis were undetectable in both species' tissues.

Recently, a global proteomics technique has revealed proteins expressed in individual human ocular tissues ${ }^{42}$ although not quantitatively. Various human eye proteome studies have detected CES1 in cornea, vitreous, RPE/choroid, and retina but not in aqueous humor. ${ }^{42}$ Our quantitative data lists all of these tissues as CES1-positive with the exception of pig retina and pig aqueous humor (Table 4). Other global proteomic studies conducted in pig or rabbit ocular tissues ${ }^{68,69}$ have only detected the presence of CES2 in the rabbit aqueous humor. $^{70}$ This contrasts with our studies where we could quantify CES2 in rabbit conjunctiva, rabbit retina, and rabbit choroid (Table 5).

Because we could not devise common peptide probes for pig and rabbit enzymes, a caveat remains that a comparison of absolute protein contents between these species may be biased due to the differential properties of the peptides. However, the use of exact quantities of heavy-labeled peptides ensures their coelution and identical fragmentation with the endogenous unlabeled peptide from the sample, thus allowing determination of the protein concentration, and dilution experiments have shown excellent linearity of the response. Therefore, an earlier analysis of CES1 and CES2 in other species ${ }^{71}$ using separate peptides showed only few-fold differences. Another counterargument can be made on the basis of the following: the inhibition of DME hydrolysis by CES1-preferring digitonin was much more efficient in pig than in rabbit tissues, and its inhibition in conjunctiva was less than that in cornea. Both 
findings match well with the rank order of the observed CES1 levels. Similarly, the genetically known lack of CES2 expression in the pig was reflected in a negligible inhibition of FDA hydrolysis in pig retina by verapamil, but a clear reduction of this activity was in rabbit retina. Although not conclusive, these explanations suggest that our comparative analysis of protein expression was not grossly distorted by the use of separate peptide probes.

Collectively, the poor correlation between CES levels and marker activities and the modest extent of DME or FDA inhibition both indicate that the expression and substrate profiles of CES1 and CES2 differ across species. These differences should be taken into consideration in follow-up studies. We cannot yet exclude participation by other hydrolyzing enzymes such as paraoxonases ${ }^{72}$ for the marker activities we utilized. Conclusions that are more definitive require heterologous expression of these rabbit and porcine CES isoforms and characterization of their preferred substrates and inhibitors in the future. Nevertheless, this study generated fundamental knowledge about hydrolytic activities in the eye and added to the literature on ocular metabolism in preclinical species. The present study also employed, for the first time, a quantitative proteomics approach to ocular tissues. Due to the low level of proteins detected, future studies should aim to improve the detection limit and address methods to enrich samples to enhance enzyme quantitation.

\section{CONCLUSIONS}

Our study is the first to assess the metabolism of multiple substrates and quantitative protein expression of carboxylesterases in rabbit and pig ocular tissues. Significant tissue and species differences in these parameters were found: CES1 was present in all rabbit tissues except conjunctiva and choroid, while CES2 was expressed in these two tissues and retina. Pig appeared to express CES1 in most ocular tissues and CES3 at low levels in the cornea, while AADAC was absent in both species. The enzymatic and inhibition studies suggest that, in rabbit and pig ocular tissues, additional esterases participate in the hydrolysis of NPA, DME, FDA, and procaine, with a greater contribution to DME by CES1. Our findings will advance the understanding of the ocular drug metabolism and its application to ocular drug delivery and prodrug pharmacokinetics.

\section{ASSOCIATED CONTENT}

\section{SI Supporting Information}

The Supporting Information is available free of charge at https://pubs.acs.org/doi/10.1021/acs.molpharmaceut.0c01154.

Tables of chromatography gradient program data and MRM parameters for the analysis of CESs and AADAC peptides and figures of Michaelis-Menten kinetics of NPA, DME, and FDA hydrolysis, inhibition of NPA hydrolysis in pig cornea using general and human isoform-selective inhibitors, inhibition of DME hydrolysis by digitonin, inhibition of FDA hydrolysis by human CES2-selective inhibitors, and correlation between hydrolytic activities and CES isozyme contents in pig and rabbit ocular tissues (PDF)

\section{AUTHOR INFORMATION}

\section{Corresponding Author}

Paavo Honkakoski - School of Pharmacy, University of Eastern Finland, 70210 Kuopio, Finland; Division of Pharmacotherapy and Experimental Therapeutics, Eshelman School of Pharmacy, University of North Carolina at Chapel Hill, Chapel Hill, North Carolina 27599-7569, United States; 10 orcid.org/0000-0002-4332-3577; Phone: +358 40355 2490; Email: paavo.honkakoski@uef.fi

\section{Authors}

Anam Hammid - School of Pharmacy, University of Eastern Finland, 70210 Kuopio, Finland

John K. Fallon - Division of Pharmacoengineering and Molecular Pharmaceutics, Eshelman School of Pharmacy, University of North Carolina at Chapel Hill, Chapel Hill, North Carolina 27599-7355, United States; 이이.org/ 0000-0003-1848-0121

Toni Lassila - Admescope Ltd, 90620 Oulu, Finland

Giulia Salluce - Centro Singular de Investigación en Química Biolóxica e Materiais Moleculares (CiQUS), Departamento de Química Orgánica, Universidade de Santiago de Compostela, 15782 Santiago de Compostela, Spain

Philip C. Smith - Division of Pharmacoengineering and Molecular Pharmaceutics, Eshelman School of Pharmacy, University of North Carolina at Chapel Hill, Chapel Hill, North Carolina 27599-7355, United States

Ari Tolonen - Admescope Ltd, 90620 Oulu, Finland

Achim Sauer - Department of Drug Discovery Sciences, Boehringer Ingelheim Pharma GmbH \& Co. KG, 88397 Biberach, Germany; (i) orcid.org/0000-0001-9980-0662

Arto Urtti - School of Pharmacy, University of Eastern

Finland, 70210 Kuopio, Finland; Institute of Chemistry, Saint Petersburg State University, 198584 Saint Petersburg, Russia; Faculty of Pharmacy, University of Helsinki, 00790 Helsinki,

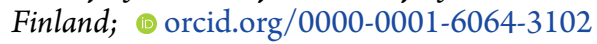

Complete contact information is available at:

https://pubs.acs.org/10.1021/acs.molpharmaceut.0c01154

\section{Notes}

The authors declare no competing financial interest.

\section{ACKNOWLEDGMENTS}

Grant support from the EU-ITN project OCUTHER (H2020MSCA-ITN-2016, grant number 722717) and Doctoral Programme in Drug Research (University of Eastern Finland) is acknowledged. The authors would like to thank Dr. Melina Malinen and Dr. Kati-Sisko Vellonen for their contribution in proteomics method development and optimization and Mrs. Lea Pirskanen for her technical assistance in the work.

\section{ABBREVIATIONS}

AADAC, arylacetamide deacetylase; ACN, acetonitrile; ATP, adenosine triphosphate; BSA, bovine serum albumin; CES, carboxylesterase; DPBS, Dulbecco's phosphate-buffered saline; DME, D-luciferin methyl ester; DMSO, dimethyl sulfoxide; DTT, dithiothreitol; FDA, fluorescein diacetate; LC, liquid chromatography; LLOQ, lower limit of quantitation; LLOD, lower limit of detection; MRM, multiple reaction monitoring; MS, mass spectrometry; NPA, 4-nitrophenol acetate; PABA, $p$ aminobenzoic acid; PBS, phosphate-buffered saline; PMSF, phenylmethylsulfonyl fluoride; rh, recombinant human; RPE, 
retinal pigment epithelium; SIL, stable isotope labeled; SPE, solid phase extraction

\section{REFERENCES}

(1) Satoh, T.; Hosokawa, M. Structure, Function and Regulation of Carboxylesterases. Chem.-Biol. Interact. 2006, 162 (3), 195-211.

(2) Di, L. The Impact of Carboxylesterases in Drug Metabolism and Pharmacokinetics. Curr. Drug Metab. 2019, 20 (2), 91-102.

(3) Lian, J.; Nelson, R.; Lehner, R. Carboxylesterases in Lipid Metabolism: From Mouse to Human. Protein Cell 2018, 9 (2), 178195.

(4) Hosokawa, M.; Maki, T.; Satoh, T. Characterization of Molecular Species of Liver Microsomal Carboxylesterases of Several Animal Species and Humans. Arch. Biochem. Biophys. 1990, 277 (1), 219-227.

(5) Fleming, C. D.; Bencharit, S.; Edwards, C. C.; Hyatt, J. L.; Tsurkan, L.; Bai, F.; Fraga, C.; Morton, C. L.; Howard-Williams, E. L.; Potter, P. M.; et al. Structural Insights into Drug Processing by Human Carboxylesterase 1: Tamoxifen, Mevastatin, and Inhibition by Benzil. J. Mol. Biol. 2005, 352 (1), 165-177.

(6) Satoh, T.; Hosokawa, M. The Mammalian Carboxylesterases: From Molecules to Functions. Annu. Rev. Pharmacol. Toxicol. 1998, 38, 257-288.

(7) Redinbo, M. R.; Bencharit, S.; Potter, P. M. Human Carboxylesterase 1: From Drug Metabolism to Drug Discovery. Biochem. Soc. Trans. 2003, 31 (3), 620-624.

(8) Lee, V. H. L.; Limoto, D. S.; Takemoto, K. A. Subcellular Distribution of Esterases in the Bovine Eye. Curr. Eye Res. 1982, 2 (12), 869-876.

(9) Sanghani, S. P.; Sanghani, P. C.; Schiel, M. A.; Bosron, W. F. Human Carboxylesterases: An Update on CES1, CES2 and CES3. Protein Pept. Lett. 2009, 16 (10), 1207-1214.

(10) Holmes, R. S.; Wright, M. W.; Laulederkind, S. J. F.; et al. Recommended Nomenclature for Five Mammalian Carboxylesterase Gene Families: Human, Mouse, and Rat Genes and Proteins. Mamm. Genome. 2010, 21 (9-10), 427-441.

(11) Ross, M. K.; Borazjani, A. Enzymatic Activity of Human Carboxylesterases. Current protocols in toxicology 2007, 33 (1), 4-24.

(12) Imai, T. Human Carboxylesterase Isozymes: Catalytic Properties and Rational Drug Design. Drug Metab. Pharmacokinet. 2006, 21 (3), 173-185.

(13) Hou, J.; Yang, L.; Lei, W.; Cheng, H.-L.; Jin, Q.; Wang, D.-D.; Zou, L.-W.; Lv, X.; Ge, G.-B. A Bioluminescent Sensor for Highly Selective and Sensitive Detection of Human Carboxylesterase 1 in Complex Biological Samples. Chem. Commun. 2016, 52 (15), 31833186.

(14) Wang, D.; Zou, L.; Jin, Q.; Hou, J.; Ge, G.; Yang, L. Human Carboxylesterases: A Comprehensive Review. Acta Pharm. Sin. B 2018, 8 (5), 699-712.

(15) Alexson, S. E. H.; Diczfalusy, M.; Halldin, M.; Swedmark, S. Involvement of Liver Carboxylesterases in the in Vitro Metabolism of Lidocaine. Drug Metab. Dispos. 2002, 30 (6), 643-647.

(16) Fukami, T.; Kariya, M.; Kurokawa, T.; Iida, A.; Nakajima, M. Comparison of Substrate Specificity among Human Arylacetamide Deacetylase and Carboxylesterases. Eur. J. Pharm. Sci. 2015, 78, 4753.

(17) Green, V. S.; Stott, D. E.; Diack, M. Assay for Fluorescein Diacetate Hydrolytic Activity: Optimization for Soil Samples. Soil Biol. Biochem. 2006, 38 (4), 693-701.

(18) Watanabe, A.; Fukami, T.; Nakajima, M.; Takamiya, M.; Aoki, Y.; Yokoi, T. Human Arylacetamide Deacetylase Is a Principal Enzyme in Flutamide Hydrolysis. Drug Metab. Dispos. 2009, 37 (7), 15131520.

(19) Watanabe, A.; Fukami, T.; Takahashi, S.; Kobayashi, Y.; Nakagawa, N.; Nakajima, M.; Yokoi, T. Arylacetamide Deacetylase Is a Determinant Enzyme for the Difference in Hydrolase Activities of Phenacetin and Acetaminophen. Drug Metab. Dispos. 2010, 38 (9), $1532-1537$.

(20) Yanjiao, X.; Chengliang, Z.; Xiping, L.; Tao, W.; Xiuhua, R.; Dong, L. Evaluation of the Inhibitory Effects of Antihypertensive
Drugs on Human Carboxylesterase In Vitro. Drug Metab. Pharmacokinet. 2013, 28 (6), 468-474.

(21) Kobayashi, Y.; Fukami, T.; Nakajima, A.; Watanabe, A.; Nakajima, M.; Yokoi, T. Species Differences in Tissue Distribution and Enzyme Activities of Arylacetamide Deacetylase in Human, Rat, and Mouse. Drug Metab. Dispos. 2012, 40 (4), 671-679.

(22) Heikkinen, E. M.; del Amo, E. M.; Ranta, V. P.; Urtti, A.; Vellonen, K. S.; Ruponen, M. Esterase Activity in Porcine and Albino Rabbit Ocular Tissues. Eur. J. Pharm. Sci. 2018, 123 (July), 106-110.

(23) Aldridge, W. N. Serum Esterases. 1. Two Types of Esterase (A and B) Hydrolysing p-Nitrophenyl Acetate, Propionate and Butyrate, and a Method for Their Determination. Biochem. J. 1953, 53 (1), 110.

(24) Kudo, S.; Umehara, K.; Hosokawa, M.; Miyamoto, G.; Chiba, K.; Satoh, T. Phenacetin Deacetylase Activity in Human Liver Microsomes: Distribution, Kinetics, and Chemical Inhibition and Stimulation. J. Pharmacol. Exp. Ther. 2000, 294 (1), 80-88.

(25) Yang, L.; Li, X.; Tang, H.; Gao, Z.; Zhang, K.; Sun, K. A Unique Role of Carboxylesterase 3 (Ces3) in $\beta$-Adrenergic SignalingStimulated Thermogenesis. Diabetes 2019, 68 (6), 1178-1196.

(26) Holmes, R. S.; Cox, L. A.; VandeBerg, J. L. Mammalian Carboxylesterase 5: Comparative Biochemistry and Genomics. Comp. Biochem. Physiol., Part D: Genomics Proteomics 2008, 3 (3), 195-204.

(27) Hosokawa, M. Structure and Catalytic Properties of Carboxylesterase Isozymes Involved in Metabolic Activation of Prodrugs. Molecules 2008, 13 (2), 412-431.

(28) Holmes, R. S.; Cox, L. A.; VandeBerg, J. L. A New Class of Mammalian Carboxylesterase CES6. Comp. Biochem. Physiol., Part D: Genomics Proteomics 2009, 4 (3), 209-217.

(29) Yoshida, T.; Fukami, T.; Kurokawa, T.; Gotoh, S.; Oda, A.; Nakajima, M. Difference in Substrate Specificity of Carboxylesterase and Arylacetamide Deacetylase between Dogs and Humans. Eur. J. Pharm. Sci. 2018, 111, 167-176.

(30) del Amo, E. M.; Rimpelä, A.-K.; Heikkinen, E.; Kari, O. K.; Ramsay, E.; Lajunen, T.; Schmitt, M.; Pelkonen, L.; Bhattacharya, M.; Richardson, D.; et al. Pharmacokinetic Aspects of Retinal Drug Delivery. Prog. Retinal Eye Res. 2017, 57, 134-185.

(31) Duvvuri, S.; Majumdar, S.; Mitra, A. K. Role of Metabolism in Ocular Drug Delivery. Curr. Drug Metab. 2004, 5 (6), 507-515.

(32) Nakamura, M.; Shirasawa, E.; Hikida, M. Characterization of Esterases Involved in the Hydrolysis of Dipivefrin Hydrochloride. Ophthalmic Res. 1993, 25 (1), 46-51.

(33) Redell, M. A.; Yang, D. C.; Lee, V. H. L. The Role of Esterase Activity in the Ocular Disposition of Dipivalyl Epinephrine in Rabbits. Int. J. Pharm. 1983, 17 (2-3), 299-312.

(34) Sjöquist, B.; Basu, S.; Byding, P.; Bergh, K.; Stjernschantz, J. The Pharmacokinetics of a New Antiglaucoma Drug, Latanoprost, in the Rabbit. Drug Metab. Dispos. 1998, 26 (8), 745-754.

(35) Saarinen-Savolainen, P.; Järvinen, T.; Suhonen, P.; Urtti, A. Amphiphilic Properties of Pilocarpine Prodrugs. Int. J. Pharm. 1996, 133 (1-2), 171-178.

(36) Volotinen, M.; Hakkola, J.; Pelkonen, O.; Vapaatalo, H.; Mäenpää, J. Metabolism of Ophthalmic Timolol: New Aspects of an Old Drug. Basic Clin. Pharmacol. Toxicol. 2011, 108 (5), 297-303.

(37) Macha, S.; Mitra, A. K. Ocular Disposition of Ganciclovir and Its Monoester Prodrugs by Microdialysis Following Intravitreal Administration. Drug Metab. Dispos. 2002, 30 (6), 670-675.

(38) Heikkinen, E. M.; Ruponen, M.; Jasper, L.-M.; Leppänen, J.; Hellinen, L.; Urtti, A.; Auriola, S.; Rautio, J.; Vellonen, K.-S. Prodrug Approach for Posterior Eye Drug Delivery: Synthesis of Novel Ganciclovir Prodrugs and in Vitro Screening with Cassette Dosing. Mol. Pharmaceutics 2020, 17 (6), 1945-1953.

(39) Druzgala, P.; Wu, W.-M.; Bodor, N. Ocular Absorption and Distribution of Loteprednol Etabonate, a Soft Steroid, in Rabbit Eyes. Curr. Eye Res. 1991, 10 (10), 933-937.

(40) Lee, V. H. L.; Chang, S. C.; Oshiro, C. M.; Smith, R. E. Ocular Esterase Composition in Albino and Pigmented Rabbits: Possible Implications in Ocular Prodrug Design and Evaluation. Curr. Eye Res. 1985, 4 (11), 1117-1125. 
(41) Lee, V. H. L.; Stratford, R. E.; Morimoto, K. W. Age-Related Changes in Esterase Activity in Rabbit Eyes. Int. J. Pharm. 1983, 13 (2), 183-195.

(42) Ahmad, M. T.; Zhang, P.; Dufresne, C.; Ferrucci, L.; Semba, R. D. The Human Eye Proteome Project: Updates on an Emerging Proteome. Proteomics 2018, 18 (5-6), 1700394.

(43) Argikar, U. A.; Dumouchel, J. L.; Dunne, C. E.; Bushee, A. J. Ocular Non-P450 Oxidative, Reductive, Hydrolytic, and Conjugative Drug Metabolizing Enzymes. Drug Metab. Rev. 2017, 49 (3), 372-394.

(44) Küblbeck, J.; Reinisalo, M.; Mustonen, R.; Honkakoski, P. UpRegulation of CYP Expression in Hepatoma Cells Stably Transfected by Chimeric Nuclear Receptors. Eur. J. Pharm. Sci. 2010, 40 (4), 263272.

(45) Prasad, B.; Gaedigk, A.; Pearce, R. E.; Leeder, J. S.; Boberg, M.; Bhatt, D. K.; Vrana, M.; Mehrotra, A. Age-Dependent Absolute Abundance of Hepatic Carboxylesterases (CES1 and CES2) by LCMS/MS Proteomics: Application to PBPK Modeling of Oseltamivir In Vivo Pharmacokinetics in Infants. Drug Metab. Dispos. 2017, 45 (2), 216-223.

(46) Tabata, T.; Katoh, M.; Tokudome, S.; Nakajima, M.; Yokoi, T. Identification of the Cytosolic Carboxylesterase Catalyzing the $5^{\prime}$ Deoxy-5-Fluorocytidine Formation from Capecitabine in Human Liver. Drug Metab. Dispos. 2004, 32 (10), 1103-1110.

(47) Bartke, A.; Musto, N.; Caldwell, B. V.; Behrman, H. R. Effects of a Cholesterol Esterase Inhibitor and of Prostaglandin F2 $\alpha$ on Testis Cholesterol and on Plasma Testosterone in Mice. Prostaglandins 1973, 3 (1), 97-104.

(48) Ghobadi Nejad, Z.; Yaghmaei, S.; Moghadam, N.; Sadeghein, B. Some Investigations on Protease Enzyme Production Kinetics Using Bacillus Licheniformis BBRC 100053 and Effects of Inhibitors on Protease Activity. Int. J. Chem. Eng. 2014, 2014, 1-6.

(49) Wang, J.; Williams, E. T.; Bourgea, J.; Wong, Y. N.; Patten, C. J. Characterization of Recombinant Human Carboxylesterases: Fluorescein Diacetate as a Probe Substrate for Human Carboxylesterase 2. Drug Metab. Dispos. 2011, 39 (8), 1329-1333.

(50) Jewell, C.; Ackermann, C.; Payne, N. A.; Fate, G.; Voorman, R.; Williams, F. M. Specificity of Procaine and Ester Hydrolysis by Human, Minipig, and Rat Skin and Liver. Drug Metab. Dispos. 2007, 35 (11), 2015-2022.

(51) Dhananjeyan, M. R.; Bykowski, C.; Trendel, J. A.; Sarver, J. G.; Ando, H.; Erhardt, P. W. Simultaneous Determination of Procaine and Para-Aminobenzoic Acid by LC-MS/MS Method. J. Chromatogr. B: Anal. Technol. Biomed. Life Sci. 2007, 847 (2), 224-230.

(52) Lassila, T.; Rousu, T.; Mattila, S.; Chesné, C.; Pelkonen, O.; Turpeinen, M.; Tolonen, A. Formation of GSH-Trapped Reactive Metabolites in Human Liver Microsomes, S9 Fraction, HepaRG-Cells, and Human Hepatocytes. J. Pharm. Biomed. Anal. 2015, 115, 345-351.

(53) Zou, L.-W.; Jin, Q.; Wang, D.-D.; Qian, Q.-K.; Hao, D.-C.; Ge, G.-B.; Yang, L. Carboxylesterase Inhibitors: An Update. Curr. Med. Chem. 2018, 25 (14), 1627-1649.

(54) Tarkiainen, K. Pharmacogenetics of Carboxylesterase. Ph.D. Dissertation, University of Helsinki, Helsinki, Finland, 2017.

(55) Yanjiao, X.; Chengliang, Z.; Xiping, L.; Tao, W.; Xiuhua, R.; Dong, L. Evaluation of the Inhibitory Effects of Antihypertensive Drugs on Human Carboxylesterase in Vitro. Drug Metab. Pharmacokinet. 2013, 28 (6), 468-474.

(56) Bawono, P.; Dijkstra, M.; Pirovano, W.; Feenstra, A.; Abeln, S.; Heringa, J. Multiple Sequence Alignment. Methods Mol. Biol. 2017, $1525,167-189$.

(57) Pundir, S.; Martin, M. J.; O'Donovan, C. UniProt Tools. Current protocols in bioinformatics 2016, 53 (1), 1-29.

(58) Uchida, Y.; Tachikawa, M.; Obuchi, W.; Hoshi, Y.; Tomioka, Y.; Ohtsuki, S.; Terasaki, T. A Study Protocol for Quantitative Targeted Absolute Proteomics (QTAP) by LC-MS/MS: Application for InterStrain Differences in Protein Expression Levels of Transporters, Receptors, Claudin-5, and Marker Proteins at the Blood-Brain Barrier in DdY, FVB, And C57BL/6J Mice. Fluids Barriers CNS 2013, 10 (1), $1-22$.
(59) Khatri, R.; Fallon, J. K.; Rementer, R. J. B.; Kulick, N. T.; Lee, C. R.; Smith, P. C. Targeted Quantitative Proteomic Analysis of Drug Metabolizing Enzymes and Transporters by Nano LC-MS/MS in the Sandwich Cultured Human Hepatocyte Model. J. Pharmacol. Toxicol. Methods 2019, 98 (April), 106590.

(60) Qasem, R. J.; Fallon, J. K.; Nautiyal, M.; Mosedale, M.; Smith, P. C. Differential Detergent Fractionation of Membrane Protein From Small Samples of Hepatocytes and Liver Tissue for Quantitative Proteomic Analysis of Drug Metabolizing Enzymes and Transporters. J. Pharm. Sci. 2021, 110 (1), 87-96.

(61) Lee, V. H. L. Esterase Activities in Adult Rabbit Eyes. J. Pharm. Sci. 1983, 72 (3), 239-244.

(62) Landowski, C. P.; Lorenzi, P. L.; Song, X.; Amidon, G. L. Nucleoside Ester Prodrug Substrate Specificity of Liver Carboxylesterase. J. Pharmacol. Exp. Ther. 2006, 316 (2), 572-580.

(63) Polsky-Fisher, S. L.; Cao, H.; Lu, P.; Gibson, C. R. Effect of Cytochromes P450 Chemical Inhibitors and Monoclonal Antibodies on Human Liver Microsomal Esterase Activity. Drug Metab. Dispos. 2006, 34 (8), 1361-1366.

(64) Shimizu, M.; Fukami, T.; Nakajima, M.; Yokoi, T. Screening of Specific Inhibitors for Human Carboxylesterases or Arylacetamide Deacetylase. Drug Metab. Dispos. 2014, 42 (7), 1103-1109.

(65) Basit, A.; Neradugomma, N. K.; Wolford, C.; Fan, P. W.; Murray, B.; Takahashi, R. H.; Khojasteh, S. C.; Smith, B. J.; Heyward, S.; Totah, R. A.; Kelly, E. J.; Prasad, B. Characterization of Differential Tissue Abundance of Major Non-CYP Enzymes in Human. Mol. Pharmaceutics 2020, 17 (11), 4114-4124.

(66) Sato, K.; Uchida, Y.; Pelkonen, L.; Reinisalo, M.; Urtti, A.; Tachikawa, M.; Kidron, H.; Watanabe, M.; Terasaki, T. LC-MS/MS Based Quantitation of ABC and SLC Transporter Proteins in Plasma Membranes of Cultured Primary Human Retinal Pigment Epithelium Cells and Immortalized ARPE19 Cell Line. Mol. Pharmaceutics 2017, 14 (3), 605-613.

(67) Heikkinen, E. M.; Auriola, S.; Ranta, V.-P.; Demarais, N. J.; Grey, A. C.; del Amo, E. M.; Toropainen, E.; Vellonen, K.-S.; Urtti, A.; Ruponen, M. Distribution of Small Molecular Weight Drugs into the Porcine Lens: Studies on Imaging Mass Spectrometry, Partition Coefficients, and Implications in Ocular Pharmacokinetics. Mol. Pharmaceutics 2019, 16 (9), 3968-3976.

(68) Liu, Y.; Bouhenni, R. A.; Dufresne, C. P.; Semba, R. D.; Edward, D. P. E. Differential Expression of Vitreous Proteins in Young and Mature New Zealand White Rabbits. PLoS One 2016, 11 (4), 1-15.

(69) Shan, S. W.; Tse, D. Y.-y.; Zuo, B.; To, C. h.; Liu, Q.; McFadden, S. A.; Chun, R. K.-M.; Bian, J.; Li, K. K.; Lam, T. C. Data on Differentially Expressed Proteins in Retinal Emmetropization Process in Guinea Pig Using Integrated SWATH-Based and Targeted-Based Proteomics. Data in Brief 2018, 21, 1750-1755.

(70) Stastna, M.; Behrens, A.; Noguera, G.; Herretes, S.; McDonnell, P.; Van Eyk, J. E. Proteomics of the Aqueous Humor in Healthy New Zealand Rabbits. Proteomics 2007, 7 (23), 4358-4375.

(71) Smith, P. C.; Fallon, J. K.; Zamek-Gliszczynski, M. J.; Mohutsky, M. A. Quantitative Targeted Absolute Proteomics (QTAP) for the Measurement of Carboxylesterase 1 and Carboxylesterase 2 in Human Liver and in Three Preclinical Species; poster P-197; abstract A-520. 20th International Symposium on Microsomes and Drug Oxidations (MDO), Stuttgart, Germany, May 18-22, 2014.

(72) Hashim, Z.; Ilyas, A.; Saleem, A.; Salim, A.; Zarina, S. Expression and Activity of Paraoxonase 1 in Human Cataractous Lens Tissue. Free Radical Biol. Med. 2009, 46 (8), 1089-1095. 